\title{
Pengaruh Strategi Diversifikasi terhadap Efisiensi pada Perusahaan Manufaktur yang Tercatat di Bursa Efek Indonesia
}

\author{
Anthony Halim, Claresta Hartawan Setio, \\ Titin Pranoto*, Vania Pradipta Gunawan \\ Program Studi Akuntansi, Sekolah Bisnis dan Ekonomi Universitas Prasetiya Mulya \\ BSD City Kavling Edutown I.1 , Jl. BSD Raya Utama, BSD City, Tangerang 15339
}

Keywor ds:

Efficiency, International Diversification, Related Diversification, Unrelated Diversification

Kata Kunci:

Efisiensi, Diversifikasi Internasional, Diversifikasi Terkait, Diversifikasi Tidak Terkait

\footnotetext{
*Corresponding author:
} titin.pranoto@pmbs.ac.id

\begin{abstract}
The purpose of this research is to examine the impact of Related Diversification, Unrelated Diversification and International Diversification on firm's Efficiency. Related Diversification and Unrelated Diversification were measured using Entropy index, while International Diversification was measured using proportion of export sales over total sales. Efficiency was measured using Data Envelopment Analysis - BCC Model using total assets as input variable and return on asset, return on equity, profit margin, earning per share, market to book value and Tobin's $Q$ as output variables. This research also uses five control variables which are firm's size, leverage, firm's age, liquidity and exchange rate. This research use manufacture companies which listed in Bursa Efek Indonesia on 2013-2016 as research samples. The result of this research show Related Diversification gives negative effect to Efficiency, Unrelated Diversification gives positive effect to Effiency, and no significant effect from International Diversification to Efficiency. The implication from this research indicate that Unrelated Diversification strategy is better for manufacturing firms in Indonesia and Efficiency will decrease as firm's size grow.
\end{abstract}

\section{Sari Pati}

Tujuan dari penelitian ini untuk menguji pengaruh Diversifikasi Terkait, Diversifikasi Tidak Terkait, dan Diversifikasi Internasional terhadap Efisiensi perusahaan. Tingkat Diversifikasi Terkait dan Diversifikasi Tidak Terkait diukur menggunakan entropy index, sedangkan tingkat Diversifikasi Internasional diukur dari proporsi penjualan ekspor dari total penjualan. Efisiensi perusahaan diukur menggunakan metode Data Envelopment Analysis - BCC Model dengan total aset sebagai variabel input dan return on asset, return on equity, marjin laba, laba per lembar saham, market to book value, dan Tobin's Q sebagai variabel output. Penelitian ini juga menggunakan lima variabel kontrol yaitu Ukuran Perusahaan, Struktur Modal, Umur Perusahaan, Likuiditas, dan Nilai Tukar. Penelitian ini menggunakan perusahaan manufaktur yang tercatat di Bursa Efek Indonesia selama tahun 2013-2016 sebagai sampel penelitian. Hasil penelitian menunjukkan bahwa Diversifikasi Terkait memberi pengaruh negatif terhadap Efisiensi, Diversifikasi Tidak Terkait memberi pengaruh positif terhadap Efisiensi, dan Diversifikasi Internasional tidak memberikan pengaruh signifikan terhadap Efisiensi. Implikasi hasil penelitian menunjukkan strategi diversifikasi yang terbaik untuk meningkatkan efisiensi bagi perusahaan manufaktur di Indonesia adalah Diversifikasi Tidak Terkait dan semakin besar ukuran perusahaan dapat menurunkan Efisiensi. 


\section{Pendahuluan}

Berdasarkan data Badan Pusat Statistik, rata-rata inflasi dari tahun 2007 hingga 2016, hampir mencapai $6 \%$ setiap tahunnya. Inflasi ini berdampak terhadap kegiatan perusahaan, mulai dari pembelian bahan baku hingga penjualan. Agar tetap dapat bersaing di pasar, perusahaan harus memiliki keunggulan kompetitif, salah satu caranya adalah dengan menggunakan bahan baku beserta aset lainnya secara efisien (Penrose, 1959). Efis iensi sangat penting dilakukan oleh perusahaan karena sumber daya merupakan hal yang langka (Gyan, Brahmana, dan Bakri, 2017).

Menurut Afza, Slahudin, dan Nazir (2007), strategi diversifikasi dapat meningkatkan efisiensi perusahaan dalam penggunaan sumber daya. Strategi diversifikasi merupakan bentuk pengembangan usaha dengan cara memperluas segmen bisnis secara geografis maupun jenis produk (Ansoff, 1957). Menurut Hill dan Jones (1998), bentuk diversif ikasi produk dapat dibagi menjadi Diversifikasi Terkait (related diversification) dan Diversifikasi Tidak Terkait (unrelated diversification).

Afza, Slahudin, dan Nazir (2007) menyatakan bahwa strategi diversifikasi dapat meningkatkan efisiensi perusahaan dalam penggunaan sumber dayanya. Sebaliknya, Chakrabarti, Singh, dan Mahmood (2007) menyatakan bahwa strategi diversifikasi justru dapat menghambat tujuan perusahaan untuk menyejahterakan pemegang saham, karena struktur, manajerial, dan organisasi perusahaan yang melakukan strategi diversifikasi akan menjadi semakin kompleks. Hal ini membuat penelitian ini masih menarik untuk diteliti selain penelitian terkait pengaruh strategi diversifikasi terhadap efisiensi di Indonesia masih sedikit. Pemilihan sampel di Indonesia yang merupakan negara berkembang semakin meningkatkan kemenarikan penelitian ini karena sebagai negara berkembang, kondisi ekonomi Indonesia masih mudah dipengaruhi oleh faktor politik dan ekonomi dunia sehingga cenderung belum kuat (Glinmourinse, 2014).

Penelitian dilakukan dengan tujuan untuk menguji pengaruh negatif strategi Diversifikasi Produk Terkait, Diversifikasi Produk Tidak Terkait, dan Diversifikasi Internasional terhadap Efisiensi 
perusahaan manufaktur di Indonesia. Hasil penelitian ini diharapkan memberikan masukan bagi perusahaan manufaktur ketika akan menentukan strategi diversifikasi.

Penjelasan berikutnya adalah telaah literatur dan pengembangan hipotesis. Bagian berikutnya adalah metode penelitian yang menjelaskan bagaimana penelitian dilaksanakan, dilanjutkan hasil dan diskusi, dan terakhir kesimpulan, implikasi dan keterbatasan.

\section{Telaah Literatur dan Pengembangan Hipotesis}

\section{Teori Agensi}

Pada tahun 1976, Jensen dan Meckling mengemukakan teori agensi yang menjelaskan hubungan antara prinsipal dan agen. Prinsipal adalah orang yang memperkerjakan agen untuk melakukan tugas demi kepentingan prinsipal, termasuk pendelegasian otorisasi pengambilan keputusan dari prinsipal kepada agen. Menurut Jensen dan Meckling (1976), prinsipal dan agen memiliki kepentingan yang berbeda, maka dari itu timbul konflik kepentingan di antara keduanya. Pada perusahaan yang modalnya terdiri atas saham, pemegang saham bertindak sebagai prins ipal dan manajer perusahaan bertindak sebagai agen (Jensen dan Meckling, 1976). Salah satu perbedaan kepentingan dapat dilihat dari keengganan manajer untuk membagikan dividen kepada pemegang saham karena dapat mengurangi jumlah kas yang dikontrol oleh manajer sehingga kekuatan manajer dalam mengatur perusahaan berkurang (Jensen, 1986). Semakin banyak perbedaan kepentingan antara manajer dan pemegang saham dan semakin besarnya asimetri informasi, akan menyebabkan peningkatan biaya agensi serta pengambilan keputusan yang kurang tepat bagi pemegang saham. Hal tersebut akan membuat efisiensi perusahaan akan berkurang.

\section{Teori Resource-Based}

Teori resource-based dipe lopori oleh Edith Penrose pada tahun 1959. Teori ini mengemukakan bahwa sumber daya perusahaan tidak homogen melainkan heterogen yang berarti sumber daya perusahaan memberikan karakter unik bagi setiap perusahaan. Teori resource-based memandang 
kumpulan kemampuan dan sumber daya dari suatu perusahaan yang nantinya dapat memberikan keunggulan kompetitif pada persaingan di pasar karena sumber daya merupakan sesuatu yang berharga, langka dan susah untuk digantikan. Teori resource-based yakin bahwa perusahaan dapat unggul dalam persaingan dan memperoleh keuntungan jika memiliki dan mengendalikan aset-aset dengan strategis dan efisien, baik aset berwujud maupun aset tidak berwujud (Penrose, 1959; Peteraf, 1993; Wernerfelt, 1984).

\section{Efisiensi}

Seringkali orang mengalami kebingungan antara efisiensi dan efektivitas. Efisiensi lebih berfokus pada penggunaan input minimum untuk mencapai hasil yang telah ditentukan, sedangkan efektivitas berfokus pada hasil yang optimum. Menurut Sukirno dan Sadono (2008, dalam Utama, Wahyono dan Witjaksono, 2016), sumber daya dapat dikatakan ef isien ketika seluruh sumber daya yang tersedia telah digunakan sepenuhnya dan motif penggunaannya telah sedemikian rupa sehingga tidak ada motif lain yang akan memberikan tambahan kemakmuran bagi masyarakat atau individu.

\section{Diversifikasi}

Setiap perusahaan pasti memiliki strategi untuk mengembangkan perusahaannya. Perusahaan yang memilih untuk berfokus mengembangkan hal yang telah dimiliki saat ini dengan tujuan untuk spesialisasi pada segmen pasar tertentu adalah perusahaan yang menerapkan strategi fokus (Tanwar, 2013). Sedangkan perusahaan yang menambah setidaknya satu produk baru di pasar yang berbeda dari produk utama yang dijual di pasar saat ini disebut melakukan strategi diversifikasi (Ansoff, 1957).

\section{Diversifikasi Produk}

Diversifikasi produk merupakan salah satu cara untuk meningkatkan kinerja perusahaan dengan cara mengidentifikasi peluang untuk menambah produk baru (Kotler dan Armstrong, 2008). 
Dengan melakukan diversifikasi produk, suatu perusahaan tidak akan bergantung pada satu jenis produk, tetapi perusahaan dapat mengandalkan jenis produk lainnya. Ketika salah satu produk mengalami penurunan kinerja, hal tersebut tidak akan mempengaruhi kinerja perusahaan secara langsung karena penurunan kinerja tersebut dapat diatasi oleh hasil kinerja produk lainnya (Kotler dan Armstrong, 2008). Menurut Hill dan Jones (1998), bentuk diversifikasi dibagi menjadi Diversifikasi Terkait (related diversification) dan Diversifikasi Tidak Terkait (unrelated diversification). Diversifikasi Terkait adalah strategi ketika kegiatan operasional perusahaan terdapat di beberapa sub sektor industri yang masih terkait dengan bisnis utama perusahaan dan Diversifikasi Tidak Terkait adalah ketika perusahaan memiliki beberapa bisnis yang terdapat di sub sektor industri yang berbedabeda dan saling tidak berhubungan (Tipuric dan Darabos, 2012).

\section{Diversifikasi Internasional}

Diversifikasi Internasional biasanya disebut juga sebagai diversifikasi geografis, internasionalisasi, atau diversifikasi secara global (Wiersema dan Bowen, 2011). Diversifikasi Internasional didefinis ikan sebagai perluasan jangkauan penjualan perusahaan ke lokasi geografis yang berbeda (Hitt, Hoskisson, dan Kim (1997).

\section{Pengembangan Hipotesis}

Pengaruh Diversifikasi Produk (Terkait dan Tidak Terkait) terhadap Efisiensi

Salah satu jenis strategi diversifikasi yang dapat dilakukan oleh perusahaan adalah divers if ikasi produk yaitu menambah produk lain selain produk utama karena dianggap mampu memberikan dampak positif kinerja perusahaan akibat peningkatan efisiensi dalam kegiatan operasionalnya. Menurut Hill dan Jones (1998), diversifikasi produk dibagi menjadi dua bentuk yaitu Diversifikasi Terkait dan Diversifikasi Tidak Terkait, maka dari itu penelitian ini membagi diversifikasi produk menjadi Diversifikasi Terkait dan Diversifikasi Tidak Terkait. 
Menurut Chatterjee et al., 1991; Penrose, 1959; Tanriverdi et al., 2005 dalam Muzyrya (2010), sumber daya perusahaan, pengetahuan manajerial, teknologi, dan keunggulan kompetitif perusahaan dapat digunakan untuk pengembangan produk baru yang akan dijual sehingga strategi diversifikasi secara umum dapat membuat perusahaan menjadi lebih efisien. Menurut Rumelt (1974) dan Montgomery dan Wernerfelt (1988), perusahaan yang melakukan Diversifikasi Terkait dapat menghasilkan kinerja lebih baik dibanding perusahaan yang melakukan Diversifikasi Tidak Terkait karena ketika perusahaan memasuki pasar yang terlalu berbeda dengan pasar saat ini, perusahaan akan kehilangan manfaat efisiensi dari diversifikasi dan kehilangan keunggulan kompetitifnya. Sedangkan menurut Fukui dan Ushijima (2006) dan Gary (2005) dalam Satoto (2009), Diversifikasi Terkait memberi pengaruh negatif terhadap kinerja perusahaan karena risiko terkumpul pada satu segmen yang sama. Dalam penerapan strategi Diversifikasi Terkait dibutuhkan waktu yang lama untuk menciptakan sebuah sinergi yang baik dalam suatu perusahaan (Qian, 1997). Seringkali akibat Diversifikasi Terkait, suatu perusahaan jadi salah mengambil keputusan sehingga manfaat dari Diversif ikasi Terkait tidak dapat dirasakan (Li dan Wong, 2003).

Amihud dan Lev (1981) dan Muzyrya (2010) mengatakan bahwa perusahaan yang melakukan strategi Diversifikasi Tidak Terkait akan memiliki risiko yang lebih kecil karena perusahaan tidak bergantung pada satu segmen usaha. Khanna dan Palepu (1997) juga mendukung perusahaan yang berada dalam negara berkembang untuk melakukan strategi Diversifikasi Tidak Terkait karena negara berkembang cenderung memiliki sistem informasi dan penegakkan hukum yang lemah sehingga perusahaan dapat dengan mudah masuk ke berbagai sub sektor industri. Disisi lain, Diversifikasi Tidak Terkait dikatakan tidak dapat memberikan keuntungan pada perusahaan karena sumber daya yang dimiliki be lum tentu dapat digunakan oleh lini bisnis lain yang dimiliki oleh perusahaan tersebut sehingga membuat perusahaan menjadi kurang efisien (Hall dan Lee, 1999). Harto (2005) juga mengatakan bahwa strategi Diversifikasi Tidak Terkait dapat menurunkan kinerja perusahaan yang nantinya akan membuat perusahaan menjadi tidak efisien karena perusahaan bisa memberikan subsidi 
silang yang berlebihan untuk lini bisnisnya yang mengalami kesulitan arus kas atau menderita kerugian. Semakin tinggi tingkat Diversifikasi Tidak Terkait perusahaan maka perusahaan harus lebih banyak mencari pengetahuan tentang bisnis baru tersebut, pembelajaran tersebut akan meningkatkan biaya perusahaan (Goold dan Campbell, 1998).

Berdasarkan peneliti terdahulu dan teori yang ada, besar kemungkinan bagi strategi diversifikasi produk (Diversifikasi Produk Terkait dan Diversifikasi Produk Tidak Terkait) akan memberikan pengaruh negatif terhadap Efisiensi. Ditambah lagi ketika perusahaan semakin terdiversifikasi, terdapat kemungkinan kontrol yang semakin menurun sehingga semakin besar kemungkinan manajer untuk mengambil keputusan demi kepentingannya sendiri. Keputusan yang diambil manajer tersebut dapat tidak efisien bagi perusahaan secara keseluruhan. Perusahaan di Indonesia juga dapat mengalami rintangan dalam mengaplikasikan strategi diversifikasi karena Indonesia merupakan negara berkembang memiliki asimetri informasi dan pasar yang belum sempurna (Lins dan Servaes, 2002), juga kondisi perekonomian yang belum kuat menyebabkan risiko yang dihadapi oleh perusahaan cenderung tinggi (Satoto, 2009). Selain itu, perusahaan yang berada pada negara berkembang memiliki keterbatasan dalam permodalan, teknologi, dan pekerja profesional sehingga membuat perusahaan tidak mendapat hasil yang maksimal dari strategi diversifikasi.

Berdasarkan penjelasan di atas, hasil penelitian terdahulu menunjukkan bahwa adanya pengaruh antara Diversifikasi Terkait dan Diversifikasi Tidak Terkait terhadap efisiensi dan kondisi negara berkembang dapat mempengaruhi hasil dari strategi diversifikasi. Maka hipotesis yang dibuat adalah:

H1a. Diversifikasi Terkait memberikan pengaruh negatif terhadap Efisiensi.

H1b. Diversifikasi Tidak Terkait memberikan pengaruh negatif terhadap Efisiensi.

\section{Pengaruh Diversifikasi Internasional terhadap Efisiensi}

Banyak pelaku bisnis memulai bisnisnya di dalam negeri atau di lokasi mereka tinggal. Dekatnya bisnis dengan lokasi tempat tinggal memudahkan pelaku bisnis untuk mengontrol 
perusahaan. Tetapi pada saat yang bersamaan, bisnis yang hanya beroperasi di wilayah domestik atau di dalam negeri dapat menyebabkan risiko yang tinggi karena bisnis jadi sangat bergantung pada kondisi keuangan domestik (Tyarani, 2016).

Perusahaan yang melakukan ekspansi ke luar negeri memiliki kinerja keuangan yang lebih baik daripada perusahaan yang tidak melakukan ekspansi ke luar negeri (Rugman dan Oh, 2010). Hasil dari pene litian Hennart (2007) juga mendukung pengaruh Diversifikasi Internasional terhadap kinerja perusahaan karena perusahaan dapat mencapai economies of scope, dapat menggapai sumber daya yang lebih, dan memiliki kesempatan untuk mempelajari hal baru. Selain itu, kondisi ekonomi, geografis, politik, dan integrasi kelembagaan dapat mempercepat economic of scale and economies scope sehingga perusahaan yang melakukan ekspansi ke luar negeri dapat memiliki bargaining power yang lebih besar (Kogut, 1985).

Menurut beberapa peneliti, perusahaan Diversifikasi Internasional memiliki efisiensi lebih rendah dibanding perusahaan yang hanya berada di lokal karena 1) terdapat asimetris informasi antara kantor di negara asal dengan kantor di luar negeri (Gao dan Chou, 2015); 2) Adanya perbedaan kultur, regulasi pemerintah, perkembangan ekonomi, dan fluktuasi kurs akan mempengaruhi keputusan perusahaan dalam menentukan alokasi sumber dayanya (Chang dan Wang, 2007); 3) Keterbatasan dari segi bahasa, budaya, dan peraturan sehingga akan menghambat kerja manajer (Grant, 1987); 4) kesulitan koordinasi dan kontrol antara kantor pusat dan kantor luar negeri membuat perusahaan tidak mencapai tujuan utamanya (Hitt et al., 1997; Kostova dan Zaheer, 1999); 5) biaya transportasi tinggi dan tarif yang harus dibayarkan dapat meningkatkan beban perusahaan (Contractor, 2007). Hal-hal tersebut membuat perusahaan mengalami penurunan kinerja dan menjadi tidak efisien.

Berdasarkan penelitian terdahulu, Diversifikasi Internasional akan memberikan pengaruh negatif terhadap efisiensi karena ketika tingkat internasionalitas perusahaan semakin tinggi maka semakin besar kesempatan bagi manajer untuk mengambil keputusan demi kepentingannya sendiri karena semakin kecil kontrol yang dilakukan oleh pemegang saham. Selain itu, manajer mempunyai 
keterbatasan dari budaya dan bahasa serta regulasi pemerintah yang dapat membuat perusahaan tidak beroperasi secara maksimal. Ditambah pula dengan asimetri informasi antara perusahaan di negara asal dengan perusahaan di negara lainnya juga akan meningkat sehingga menyebabkan pengambilan keputusan yang kurang efisien. Pemilihan negara yang sedang memiliki kondisi ekonomi tidak baik untuk Diversifikasi Internasional, juga dapat meningkatkan risiko kegagalan bisnis pada negara tersebut.

H2. Diversifikasi Internasional memberikan pengaruh negatif terhadap Efisiensi.

\section{Kerangka pemikiran}

\section{Gambar 1. Kerangka Pemikiran}

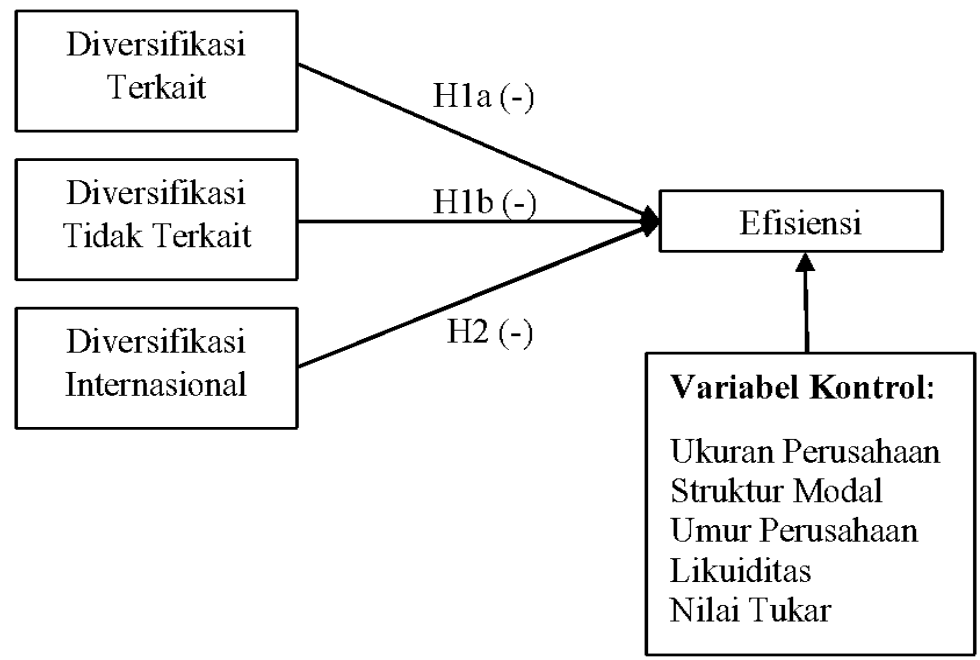

\section{Metode Penelitian}

\section{Jenis dan Sumber Data}

Jenis data yang digunakan dalam penelitian ini adalah data sekunder. Seluruh data bersumber dari S\&P Capital IQ Platform dan situs Bursa Efek Indonesia (www.idx.co.id).

\section{Populasi dan Sampel}

Penelitian ini dilakukan dengan menggunakan populasi perusahaan manufaktur yang terdaftar di BEI tahun 2013-2016. Pemilihan sampel menggunakan teknik purposive sampling untuk 
memberikan hasil yang lebih akurat dari sampel yang sesuai. Daftar perolehan sampel penelitian dije laskan dalam Tabel 1.

Dari total 89 sampel perusahaan (Tabel 1), ada 48 perusahaan yang melakukan Diversifikasi Terkait (Model 1a), 32 perusahaan melakukan Diversifikasi Tidak Terkait (Model 1b) dan 73 perusahaan melakukan Diversifikasi Internasional (Model 2). Jika dijumlahkan, Model 1a dan Model 1b hanya sebanyak 80 sampel perusahaan, hal tersebut dikarenakan sembilan (9) perusahaan dari total sampel tidak melakukan Diversifikasi Produk (Terkait dan Tidak Terkait) namun hanya melakukan Diversifikasi Internasional. Jumlah sampel pada Mode1 2 menggambarkan bahwa dari total sampel 89 perusahaan, hanya 73 sampel perusahaan yang melakukan Diversifikasi Internasional dan 16 sampel perusahaan lainnya tidak melakukan Diversifikasi Internasional.

Tabel 1 Perolehan Sampel Penelitian

\begin{tabular}{|l|r|r|}
\hline \multicolumn{1}{|c|}{ Deskripsi } & \multicolumn{1}{|c|}{$\begin{array}{c}\text { Sampel } \\
\text { per Tahun }\end{array}$} & $\begin{array}{c}\text { Total } \\
\text { Sampel }\end{array}$ \\
\hline Jumlah perusahaan manufaktur yang tercatat di BEI tahun 2013-2016 & 147 & 588 \\
\hline $\begin{array}{l}\text { Jumlah perusahaan manufaktur yang baru listing atau relisting dalam tahun } \\
\text { 2013-2016 }\end{array}$ & $(9)$ & $(36)$ \\
\hline Jumlah perusahaan manufaktur yang delisted dalam tahun 2013-2016 & $(1)$ & $(4)$ \\
\hline $\begin{array}{l}\text { Jumlah perusahaan manufaktur yang memiliki tahun buku selain bulan } \\
\text { Desember }\end{array}$ & $(2)$ & $(8)$ \\
\hline $\begin{array}{l}\text { Jumlah perusahaan manufaktur dengan data yang tidak lengkap selama tahun } \\
\text { 2013-2016 }\end{array}$ & $(7)$ & $(28)$ \\
\hline $\begin{array}{l}\text { Jumlah perusahaan manufaktur yang tercatat merupakan saham preference dan } \\
\text { saham seri B }\end{array}$ & $(8)$ \\
\hline $\begin{array}{l}\text { Jumlah perusahaan manufaktur yang memiliki eku itas negatif selama tahun } \\
\text { 2013-2016 }\end{array}$ & $(9)$ & $(36)$ \\
\hline Jumlah perusahaan dengan mata uang pelaporan selain Rupiah & $(21)$ & $(104)$ \\
\hline Jumlah perusahaan manufaktur yang tidak melakukan diversifikasi & $(7)$ & $(28)$ \\
\hline \begin{tabular}{l} 
Juml ah sampel perusahaan \\
\hline
\end{tabular}
\end{tabular}

Pengukuran dan Operasionalisasi Variabel Penelitian

Tabel 2 Ope rasionalisasi Variabel Model Pene litian

\begin{tabular}{|c|c|c|c|}
\hline No & Nama Variabel & Simbol & Cara Mengukur \\
\hline \multicolumn{3}{|c|}{ Variabel Dependen } \\
\hline 1. & Efisiensi & E & Model BCC - Data Envelopment Analysis \\
\hline \multicolumn{3}{|c}{ Variabel Independen } \\
\hline
\end{tabular}




\begin{tabular}{|c|c|c|c|}
\hline 1. & $\begin{array}{l}\text { Diversifikasi Produk } \\
\text { Terkait }\end{array}$ & DR & $D R=\sum_{j=1}^{M} D R_{j} x P_{j}$ \\
\hline 2. & $\begin{array}{l}\text { Diversifikasi Produk } \\
\text { Tidak Terkait }\end{array}$ & DU & $D U=\sum_{j=1}^{M} P_{j} x \ln \left(\frac{1}{P_{j}}\right)$ \\
\hline 3. & $\begin{array}{l}\text { Diversifikasi } \\
\text { Internasional }\end{array}$ & ID & $\frac{\text { total ekspor }}{\text { total penjualan }}$ \\
\hline \multicolumn{4}{|c|}{ Variabel Kontrol } \\
\hline 1. & Ukuran Perusahaan & SIZE & $\ln ($ total aset $)$ \\
\hline 2. & $\begin{array}{l}\text { Struktur Modal } \\
\quad \text { (Leverage) }\end{array}$ & LEV & $\frac{\text { Total Utang Bank }}{\text { Total Aset }}$ \\
\hline 3. & Umur Perusahaan & AGE & $\begin{array}{l}\text { In (Tahun laporan keuangan terakhir - } \\
\text { Tahun perusahaan berdiri) }\end{array}$ \\
\hline 4. & Likuiditas & LIQ & $\frac{\text { Aset Lancar }}{\text { Liabilitas Jangka Pendek }}$ \\
\hline 5. & Nilai Tukar & EX & $\begin{array}{l}\text { Nilai Tengah Kurs Rupiah terhadap Dolar } \\
\text { Amerika }\end{array}$ \\
\hline
\end{tabular}

Untuk mengukur Efisiensi diaplikasikan model BCC yaitu model yang dikemukakan oleh Banker, Charnes, dan Cooper pada tahun 1984 sebagai perkembangan dari model CCR yang dikemukan oleh Charnes, Cooper, dan Rhodes. Model BCC digunakan untuk mengevaluasi efisiensi dari decision making units (DMUs) berdasarkan batas efisien terhadap variable return to scale (VRS). Pada model BCC diyakini bahwa setiap penambahan input tidak akan meningkatkan output yang sebanding dengan penambahan input tersebut, melainkan output bisa melebihi atau kurang dari penambahan input tersebut. Rasio dari perhitungan BCC menunjukkan skala efisiensi, pada saat nilainya 1 berarti perusahaan efisien. Nilai rasio yang mendekati satu (1) mengarahkan perusahaan untuk mencapai economies of scale karena bertambahnya return to scale, sedangkan ketika terjadi penurunan return to scale maka akan mengarah ke diseconomies of scale (Allaf, 2012).

Untuk mengukur Efisiensi digunakan Microsoft Excel dengan mengaplikasikan BCC envelopment model sebagai berikut:

$$
?^{*}=\theta
$$




$$
\begin{array}{ll}
\sum_{j=1}^{\text {batasan }} \lambda_{J} x_{i j} \leq \theta x_{i 0} & \mathrm{i}=1,2, \ldots, \mathrm{m} ; \\
\sum_{j=1}^{n} \lambda_{j} y_{r j} \geq y_{r o} & \mathrm{r}=1,2, \ldots, \mathrm{s} ; \\
\sum_{j=1}^{n} \lambda_{j}=1 & \mathrm{j}=1,2, \ldots, \mathrm{n} \\
\varrho_{j} \geq 0 &
\end{array}
$$

Keterangan:

$\theta \quad=$ Efisiensi

$\mathrm{m} \quad=$ jumlah input

$\mathrm{s} \quad=$ jumlah output

$\mathrm{n} \quad=$ jumlah DMU

$\mathrm{X}_{\mathrm{ij}} \quad=$ jumlah input ke-i dari DMU ke-j

$Y_{r j} \quad=$ jumlah output ke-r dari DMU ke-j

回 $]_{j}=$ bobot DMU j untuk DMU yang dihitung

Menurut Doaei, Anuar, dan Ismail (2015), terdapat satu (1) input dan dan enam (6) output yang cocok untuk mengukur efisiensi dengan model BCC (Tabel 3).

Tabel 3 Input dan Outputs BCC Model

\begin{tabular}{|l|l|}
\hline \multicolumn{2}{|l|}{ Input } \\
\hline 1. Logaritma Natural dari Total Aset & $\ln$ (total aset) \\
\hline Outputs & $R O A=\frac{\text { laba neto }}{\text { total aset }}$ \\
\hline 1. Return on Asset & $R O E=\frac{\text { laba neto }}{\text { total ekuitas }}$ \\
\hline 2. Return on Equity & $P M=\frac{\text { laba neto }}{\text { pendapatan penjualan }}$ \\
\hline 3. Marjin Laba (Profit Margin / PM) & $M B=\frac{\text { harga pasar per lembar saham }}{\text { harga buku per lembar saham }}$ \\
\hline 4. Market to Book Value (MB) & \\
\hline
\end{tabular}




\begin{tabular}{|l|l|}
\hline $\begin{array}{l}\text { 5. Laba per Lembar Saham (Earning } \\
\text { per Share / EPS) }\end{array}$ & $E P S=\frac{\text { laba neto }}{\text { jumlah saham beredar }}$ \\
\hline 6. Tobin's Q (TQ) & $T Q=\frac{\text { harga pasar dari ekuitas }+ \text { harga buku dari liabilitas }}{\text { harga buku dari total aset }}$ \\
\hline
\end{tabular}

Untuk mengukur Diversifikasi Produk digunakan entropy index / entropy measure yang diperkenalkan oleh Jacquemin dan Berry (1979). Pemilihan penggunaan entropy index karena pengukuran entropy yang lebih objektif dan mempertimbangkan kontribusi tiap segmen usaha terhadap total penjualan perusahaan. Pengukuran Entropy mencerminkan tiga elemen diversifikasi, yaitu jumlah segmen yang terdapat dalam perusahaan, distribusi penjualan setiap segmen usaha, dan tingkat keterkaitan sub sektor industri antar setiap segmen (Palepu, 1985).

Pada penelitian ini, dalam pengklasifikasian segmen perusahaan, digunakan SIC (Standard Industrial Classification) Codes, mengacu kepada Palepu (1985). Kode SIC tersebut telah digunakan sejak 1937 oleh pemerintah Amerika Serikat untuk menentukan area industri dan masih sering digunakan hingga saat ini. Setiap industri yang dimiliki perusahaan diklasifikasikan ke dalam empat digit kode SIC untuk menentukan perbedaan golongan setiap segmen industri. Produk yang tergolong dalam empat digit kode SIC yang memiliki dua kode grup industri (dua kode depan) yang sama, digolongkan sebagai terkait. Sedangkan produk yang memiliki dua kode grup industri SIC yang berbeda, tergolong tidak terkait (Palepu, 1985).

Perhitungan total entropy sebagai berikut:

$$
\begin{gathered}
D T=D R+D U \\
D T=\sum_{i=1}^{N} P_{i} x \ln \left(\frac{1}{P_{i}}\right)
\end{gathered}
$$

Keterangan:

Pengaruh Strategi Diversifikasi terhadap Efisiensi pada Perusahaan Manufaktur yang Tercatat di Bursa Efek Indonesia | 1-28 
DT Total diversification entropy

$N \quad$ Jumlah kelompok industri segmen

$P_{i} \quad$ Rasio penjualan segmen $i$ dari total penjualan perusahaan

Perhitungan unrelated entrophy sebagai berikut:

$$
D U=\sum_{j=1}^{M} P_{j} x \ln \left(\frac{1}{P_{j}}\right)
$$

Keterangan:

DU Unrelated diversification entropy

$M \quad$ Jumlah kelompok grup industri $(\mathrm{n} \geq \mathrm{M})$

$P_{j} \quad$ Rasio penjualan segmen $j$ dari total penjualan perusahaan

Perhitungan related entrophy sebagai berikut:

$$
D R=D T-D U
$$

Keterangan:

$\begin{array}{ll}D T & \text { Total diversification entropy } \\ D U & \text { Unrelated diversification entropy } \\ D R & \text { Related diversification entropy }\end{array}$

Untuk mengukur Diversif ikasi Internasional, digunakan rumus perhitungan rasio dari penjualan secara ekspor dibagi dengan total penjualan (Doaei et al., 2015).

$$
\text { Diversifikasi internasional }=\frac{\text { Total ekspor }}{\text { Total Penjualan }}
$$

\section{Model Penelitian}

Model 1a

$\mathrm{E}_{\mathrm{it}}=$ ? +$\left.\left.\left.\left.]_{1} \mathrm{DR}_{\mathrm{it}}+\right]_{2} \mathrm{SIZE}_{\mathrm{it}}+\right]_{3} \mathrm{LEV}_{\mathrm{it}}+?_{4} \mathrm{AGE}_{\mathrm{it}}+\right]_{5} \mathrm{LIQ}_{\mathrm{it}}+\right]_{6} \mathrm{EX}_{\mathrm{t}}+?_{\mathrm{it}}$ 


\section{$\underline{\text { Model 1b }}$}

$\mathrm{E}_{\mathrm{it}}=$ ? +$\left.\left.\left.\left.]_{1} \mathrm{DU}_{\mathrm{it}}+\right]_{2} \mathrm{SIZE}_{\mathrm{it}}+?_{3} \mathrm{LEV}_{\mathrm{it}}+\right]_{4} \mathrm{AGE}_{\mathrm{it}}+\right]_{5} \mathrm{LIQ}_{\mathrm{it}}+\right]_{6} \mathrm{EX}_{\mathrm{t}}+?_{\mathrm{it}}$

\section{$\underline{\text { Model } 2}$}

$\left.\left.\left.\left.\left.\left.\mathrm{E}_{\mathrm{it}}=?+\right]_{1} \mathrm{ID}_{\mathrm{it}}+\right]_{2} \mathrm{SIZE}_{\mathrm{it}}+\right]_{3} \mathrm{LEV}_{\mathrm{it}}+\right]_{4} \mathrm{AGE}_{\mathrm{it}}+\right]_{5} \mathrm{LIQ}_{\mathrm{it}}+\right]_{6} \mathrm{EX}_{\mathrm{t}}+?_{\mathrm{it}}$

\section{Keterangan:}

$\mathrm{E}_{\mathrm{it}} \quad=$ Tingkat Efisiensi pada perusahaan ke- $i$ di tahun ke- $t$

$i=$ Perusahaan ke- $i$

$t \quad=$ Tahun ke- $t$

? $\quad=$ Konstanta

[ $\quad=$ Koefisien regresi

$\mathrm{DR}_{\mathrm{it}} \quad=$ Tingkat Diversifikasi Produk Terkait pada perusahaan ke- $i$ di tahun ke- $t$

$\mathrm{DU}_{\mathrm{it}} \quad=$ Tingkat Diversifikasi Produk Tidak Terkait pada perusahaan ke- $i$ di tahun ke- $t$

ID $_{\text {it }}=$ Tingkat Diversifikasi Internasional pada perusahaan ke- $i$ di tahun ke- $t$

SIZE $_{\text {it }}=$ Ukuran Perusahaan pada perusahaan ke- $i$ di tahun ke- $t$

$\mathrm{LEV}_{\mathrm{it}} \quad=$ Struktur Modal (debt ratio) pada perusahaan ke- $i$ di tahun ke- $t$

$\mathrm{AGE}_{\mathrm{it}} \quad=$ Umur Perusahaan pada perusahaan ke- $i$ di tahun ke- $t$

LIQ $_{\text {it }} \quad=$ Likuiditas (rasio lancar) pada perusahaan ke- $i$ di tahun ke- $t$

$\mathrm{EX}_{\mathrm{t}} \quad=$ Nilai tengah atas kurs Rupiah terhadap Dolar Amerika di tahun ke- $t$

Q $_{\mathrm{it}} \quad=$ Error

\section{Metode Analisis Data}

Dalam penelitian ini, tipe data yang digunakan adalah data panel. Data panel adalah data yang terdiri dari cross section dan time series (Gujarati dan Porter, 2009). Pada penelitian ini dilaksanakan analisis statistik deskriptif untuk memberi gambaran data, uji asumsi klasik yang terdiri dari uji normalitas, uji multikolinearitas, uji autokolerasi, dan uji heteroskedastisitas, uji ketepatan model untuk mengetahui model regresi yang paling tepat, uji koefisien determinasi, serta uji hipotesis.

\section{Hasil dan Diskusi}

Pengolahan data di software STATA 13 dilakukan sebanyak tiga kali sesuai dengan jumlah model penelitian karena setiap model penelitian memiliki jumlah sampel yang berbeda. Pertama-tama, dilakukan analisis statistik deskriptif untuk mengetahui pergambaran data. Tabel 4 hingga Tabel 6 merupakan statistik deskriptif untuk setiap model penelitian.

a. Diversifikasi Terkait (Model 1a) 
Tabel 4 Statistik Deskriptif - Diversifikasi Terkait (Model 1a)

\begin{tabular}{|l|r|r|r|r|r|r|}
\hline Variabel & \multicolumn{1}{c|}{ Mean } & \multicolumn{1}{c|}{ Std Dev } & \multicolumn{1}{c|}{ Min } & \multicolumn{1}{c|}{ Max } & \multicolumn{1}{c|}{ Skewness } & \multicolumn{1}{c|}{ Kurtosis } \\
\hline E & 0,322 & 0,088 & 0,002 & 0,711 & 1,604 & 7,678 \\
\hline DR & 0,751 & 0,326 & 0,1 & 1,601 & 0,340 & 2,909 \\
\hline SIZE & 14,569 & 1,341 & 11,804 & 18,335 & 0,653 & 3,406 \\
\hline LEV & 0,272 & 0,212 & 0 & 0,795 & 0,312 & 2,058 \\
\hline AGE & 3,632 & 0,380 & 2,773 & 5,293 & 1,203 & 9,003 \\
\hline LIQ & 1,786 & 1,935 & 0,214 & 13,871 & 3,226 & 16,769 \\
\hline EX & 1,226 & 0,121 & 1,045 & 1,339 & $-0,478$ & 1,613 \\
\hline
\end{tabular}

Model 1a untuk menguji hipotesis 1a (pengaruh negatif Diversifikasi Terkait terhadap Efisiensi) dengan total sampel penelitian sebanyak 48 perusahaan.

E adalah Efisiensi yang diukur dengan model BCC - Data Envelopment Analysis menggunakan Microsoft Excel. DR adalah Related Diversification (Diversifikasi Produk Terkait) yang diukur menggunakan entropy index. SIZE adalah Ukuran Perusahaan yang dihitung dengan natural logaritma dari total aset perusahaan. LEV adalah leverage atau Struktur Modal yang dihitung dengan total utang bank terhadap total aset perusahaan. AGE adalah logarit ma natural dari Umur Perusahaan yang dihitung atas tahun yang diteliti dikurangi dengan tahun perusahaan berdiri. LIQ adalah Likuiditas yang dihitung dengan rasio lancar (total aset lancar terhadap total liabilitas jangka pendek). EX adalah nilai tengah atas nilai tukar dari USD (Dolar Amerika) ke Rupiah pada tahun tersebut (dalam puluhan ribu).

b. Diversifikasi Tidak Terkait (Model 1b)

Tabel 5 Statistik Deskriptif - Dive rsifikasi Tidak Terkait (Model 1b)

\begin{tabular}{|l|r|r|r|r|r|r|}
\hline \multicolumn{1}{|c|}{ Variabel } & Mean & \multicolumn{1}{c|}{ Std Dev } & \multicolumn{1}{c|}{ Min } & Max & \multicolumn{1}{c|}{ Skewness } & \multicolumn{1}{c|}{ Kurtosis } \\
\hline E & 0,349 & 0,161 & 0,211 & 1 & 2,881 & 10,989 \\
\hline DU & 0,555 & 0,333 & 0 & 1,661 & 0,510 & 4,705 \\
\hline SIZE & 14,417 & 1,813 & 11,496 & 19,383 & 0,778 & 3,020 \\
\hline LEV & 0,235 & 0,172 & 0 & 0,659 & 0,529 & 2,496 \\
\hline AGE & 3,642 & 0,499 & 1,609 & 4,585 & $-1,158$ & 6,632 \\
\hline LIQ & 1,132 & 0,817 & 0,360 & 6,847 & 3,475 & 21,554 \\
\hline EX & 1,226 & 0,121 & 1,045 & 1,339 & $-0,478$ & 1,613 \\
\hline
\end{tabular}

Model 1b untuk menguji hipotesis 1b (pengaruh negatif Diversifikasi Tidak Terkait terhadap Efisiensi) dengan total sampel penelitian sebanyak 32 perusahaan.

E adalah Efisiensi yang diukur dengan model BCC - Data Envelopment Analysis menggunakan Microsoft Excel. DU adalah Unrelated Diversification (Diversifikasi Produk Tidak Terkait) yang diukur menggunakan entropy index. SIZE adalah Ukuran Perusahaan yang dihitung dengan natural logarit ma dari total aset perusahaan. LEV adalah leverage atau Struktur Modal yang dihitung dengan total utang bank terhadap total aset perusahaan. AGE adalah logarit ma natural dari Umur Perusahaan yang dihitung atas tahun yang diteliti dikurangi dengan tahun perusahaan berdiri. LIQ adalah 
Likuiditas yang dihitung dengan rasio lancar (total aset lancar terhadap total liabilitas jangka pendek). EX adalah nilai tengah atas Nilai Tukar dari USD (Dolar Amerika) ke Rupiah pada tahun tersebut (dalam puluhan ribu).

c. Diversif ikasi Internasional (Mode1 2)

Tabel 6 Statistik Deskriptif - Dive rsifikasi Internasional (Model 2)

\begin{tabular}{|l|r|r|r|r|r|r|}
\hline \multicolumn{1}{|c|}{ Variabel } & Mean & \multicolumn{1}{c|}{ Std Dev } & \multicolumn{1}{c|}{ Min } & \multicolumn{1}{c|}{ Max } & \multicolumn{1}{l}{ Skewness } & \multicolumn{1}{l}{ Kurtosis } \\
\hline E & 0,360 & 0,170 & 0,002 & 1 & 2,374 & 8,530 \\
\hline ID & 0,169 & 0,246 & 0 & 1 & 1,977 & 6,167 \\
\hline SIZE & 14,498 & 1,453 & 11,496 & 18,335 & 0,556 & 2,913 \\
\hline LEV & 0,229 & 0,188 & 0 & 0,795 & 0,514 & 2,401 \\
\hline AGE & 3,709 & 0,437 & 1,609 & 5,293 & $-0,225$ & 8,395 \\
\hline LIQ & 1,465 & 1,588 & 0,196 & 13,871 & 4,085 & 26,412 \\
\hline EX & 1,226 & 0,121 & 1,045 & 1,339 & $-0,478$ & 1,613 \\
\hline
\end{tabular}

Model 2 untuk menguji hipotesis 2 (pengaruh negatif Diversifikasi Internasional terhadap Efisiensi) dengan total sampel penelitian sebanyak 73 perusahaan.

E adalah Efisiensi yang diukur dengan model BCC - Data Envelopment Analysis menggunakan Microsoft Excel. ID adalah Diversifikasi Internasional yang dihitung dari penjualan ke luar negeri (ekspor) terhadap total penjualan perusahaan. SIZE adalah Ukuran Perusahaan yang dihitung dengan natural logaritma dari total aset perusahaan. LEV adalah leverage atau Struktur Modal yang dihitung dengan total utang bank terhadap total aset perusahaan. AGE adalah logaritma natural dari Umur Perusahaan yang dihitung atas tahun yang diteliti dikurangi dengan tahun perusahaan berdiri. LIQ adalah Likuiditas yang dihitung dengan rasio lancar (total aset lancar terhadap total liabilitas jangka pendek). EX adalah nilai tengah atas Nilai Tukar dari USD (Dolar Amerika) ke Rupiah pada tahun tersebut (dalam puluhan ribu).

Pada Model 1a dan 2, variabel Likuiditas memiliki persebaran data yang tidak normal. Pada Model 1b, variabel Efisiensi dan Likuiditas memiliki persebaran data yang tidak normal. Persebaran data tidak normal karena tidak memiliki skewness diantara -3 hingga 3 atau tidak memiliki kurtosis diantara -10 hingga 10. Maka dari itu dilakukan teknik winsorize dengan persentase 5\% untuk memperbaiki persebaran data pada variabel yang memiliki persebaran data tidak normal yaitu Likuiditas (pada ketiga model penelitian) dan Efisiensi (pada Model 1b). Teknik winsorize sebanyak 5\% berarti data yang di bawah persentil ke-5 akan diubah menjadi sama dengan data pada persentil ke-5, sedangkan data yang berada di atas persentil ke-95 akan diturunkan menjadi sebesar data di persentil ke-95. Pada Model 1a, Likuiditas awalnya memiliki kurtosis sebesar 16,769 dan setelah 
dilakukan winsorize, kurtosis menjadi 2,909. Pada awalnya di Model 1b, Efisiensi memiliki kurtosis sebesar 10,989 dan Likuiditas sebesar 21,554, setelah dilakukan winsorize kurtosis dari Efisiensi menjadi 8,414 dan Likuiditas menjadi 3,060. Pada model 2, Likuiditas awalnya memiliki kurtosis sebesar 17,769, setelah dilakukan winsorize kurtosis menjadi 4,809. Setelah dilakukan treatment data maka seluruh variabel pada setiap model penelitian memiliki skewness dan kurtosis yang normal seperti yang tertera pada Tabel 7

Tabel 7 Hasil Uji Normalitas - Skewness \& Kurtos is

\begin{tabular}{|c|c|c|c|c|c|c|}
\hline \multirow{2}{*}{ Variabel } & \multicolumn{2}{|c|}{ Model 1a } & \multicolumn{2}{|c|}{ Model $1 \mathrm{~b}$} & \multicolumn{2}{|c|}{ Model 2} \\
\hline & Skewness & Kurtosis & Skewness & Kurtosis & Skewness & Kurtosis \\
\hline $\mathbf{E}$ & 1,604 & 7,678 & 2,441 & 8,414 & 2,374 & 8,530 \\
\hline DR & 0,340 & 2,909 & & & & \\
\hline DU & & & 0,510 & 4,705 & & \\
\hline ID & & & & & 1,977 & 6,167 \\
\hline SIZE & 0,653 & 3,406 & 0,778 & 3,020 & 0,556 & 2,913 \\
\hline LEV & 0,312 & 2,058 & 0,529 & 2,496 & 0,514 & 2,401 \\
\hline AGE & 1,203 & 9,003 & $-1,158$ & 6,632 & $-0,225$ & 8,395 \\
\hline LIQ & 1,509 & 4,231 & 0,981 & 3,060 & 1,613 & 4,809 \\
\hline EX & $-0,478$ & 1,613 & $-0,478$ & 1,613 & $-0,478$ & 1,613 \\
\hline $\mathbf{E}$ & 1,604 & 7,678 & 2,441 & 8,414 & 2,374 & 8,530 \\
\hline
\end{tabular}

Model 1a untuk menguji hipotesis 1a (pengaruh negatif Diversifikasi Terkait terhadap Efisiensi) dengan total sampel penelitian sebanyak 48 perusahaan. Model 1b untuk menguji hipotesis $1 \mathrm{~b}$ (pengaruh negatif Diversifikasi Tidak Terkait terhadap Efisiensi) dengan total sampel penelitian sebanyak 32 perusahaan. Model 2 untuk menguji hipotesis 2 (pengaruh negatif Diversifikasi Internasional terhadap Efisiensi) dengan total sampel penelitian sebanyak 73 perusahaan.

E adalah Efisiensi yang diukur dengan model BCC - Data Envelopment Analysis menggunakan Microsoft Excel. DR adalah Related Diversification (Diversifikasi Produk Terkait) yang diukur menggunakan entropy index. DU adalah Unrelated Diversification (Diversifikasi Produk Tidak Terkait) yang diukur menggunakan entropy index. ID adalah Diversifikasi Internasional yang dihitung dari penjualan ke luar negeri (ekspor) terhadap total penjualan perusahaan. SIZE adalah Ukuran Perusahaan yang dihitung dengan natural logaritma dari total aset perusahaan. LEV adalah leverage atau Struktur Modal yang dihitung dengan total utang bank terhadap total 
aset perusahaan. AGE adalah logaritma natural dari Umur Perusahaan yang dihitung atas tahun yang diteliti dikurangi dengan tahun perusahaan berdiri. LIQ adalah Likuiditas yang dihitung dengan rasio lancar (total as et lancar terhadap total liabilitas jangka pendek). EX adalah nilai tengah atas Nilai Tukar dari USD (Dolar Amerika) ke Rupiah pada tahun tersebut (dalam puluhan ribu).

\section{Analisis Pengaruh Strategi Diversifikasi Terkait Terhadap Efisiensi (Model 1a)}

Model 1a menggunakan metode regresi fixed effect robust. Penentuan metode fixed effect berdasarkan hasil uji ketepatan model. Pemilihan opsi robust untuk memperbaiki masalah heteroskedastisitas pada Model 1a (Hoechle, 2007).

Tabel 8 Hasil Regresi Variabel Penelitian - Dive rsifikasi Terkait (Model 1a)

\begin{tabular}{|c|c|c|c|}
\hline $\mathbf{E}$ & Koefisien & $P>|t|$ & Korelasi \\
\hline DR & $-0,072$ & $0,010^{* *}$ & Signifikan ( - ) \\
\hline SIZE & $-0,087$ & $0,003 * * *$ & Signifikan ( - ) \\
\hline LEV & 0,011 & 0,409 & Tidak Signifikan \\
\hline AGE & $-0,349$ & $0,054^{*}$ & Signifikan ( - ) \\
\hline LIQ & 0,026 & $0,000 * * *$ & Signifikan (+ ) \\
\hline EX & 0,127 & $0,058^{*}$ & Signifikan (+ ) \\
\hline Konstanta & 2,701 & 0,005 & \\
\hline R-s q & 0,157 & & \\
\hline Perusahaan & 48 & & \\
\hline Observasi & 192 & & \\
\hline
\end{tabular}

Tanda $* * *$ berarti signifikan pada $1 \%$; tanda $* *$ berarti signifikan pada $5 \%$; tanda $*$ berarti signifikan pada $10 \%$.

E adalah Efisiensi yang diukur dengan model BCC - Data Envelopment Analysis menggunakan Microsoft Excel. DR adalah Related Diversification (Diversifikasi Produk Terkait) yang diukur menggunakan entropy index. SIZE adalah Ukuran Perusahaan yang dihitung dengan natural logaritma dari total aset perusahaan. LEV adalah leverage atau Struktur Modal yang dihitung dengan total utang bank terhadap total aset perusahaan. AGE adalah logaritma natural dari Umur Perusahaan yang dihitung atas tahun yang diteliti dikurangi dengan tahun perusahaan berdiri. LIQ adalah Liku iditas yang dihitung dengan rasio lancar (total aset lancar terhadap total liabilitas jangka pendek). EX adalah nilai tengah atas Nilai Tukar dari USD (Dolar Amerika) ke Rupiah pada tahun tersebut (dalam puluhan ribu). 
Mengacu Tabel 8, variabel independen Diversifikasi Terkait menunjukkan hasil koefisien negatif dan korelasi signifikan. Hal ini menunjukkan bahwa Hipotesis 1a yang diajukan yaitu Diversifikasi Terkait memberi pengaruh negatif terhadap Efisiensi diterima. Doaei et al. (2015) menyatakan bahwa terdapat perbedaan kepentingan antara manajer dan pemegang saham sehingga membuat strategi diversifikasi menjadi tidak efisien. Qian (1997) berpendapat bahwa proses pembangunan sinergi pada perusahaan yang terdiversifikasi membutuhkan waktu yang lama dan biaya yang cukup besar sehingga diversifikasi tidak memberikan manfaat baik bagi efisiensi suatu perusahaan. Semakin perusahaan terdiversifikasi, mengontrol perusahaan akan semakin sulit sehingga asimetri informasi semakin meningkat. Diversifikasi Terkait juga membuat ketidakpastian pada perilaku perusahaan yang meningkatkan kesalahan pengambilan keputusan oleh perusahaan (Li dan Wong, 2003). Selain itu, risiko yang terkumpul pada satu sub sektor industri yang sama membuat perusahaan jadi terlalu bergantung pada satu kondisi sub sektor industri. Ketika sub sektor industri tersebut sedang mengalami kondisi yang buruk, kemungkinan besar perusahaan akan mengalami kondisi yang buruk.

\section{Analisis Pengaruh Strategi Diversifikasi Tidak Terkait Terhadap Efisiensi (Model 1b)}

Model 1b menggunakan metode regresi fixed effect Driscoll-Kraay. Penentuan metode fixed effect berdasarkan hasil uji ketepatan model. Pemilihan opsi Driscoll-Kraay untuk memperbaiki masalah heteroskedastisitas, autokolerasi dan cross-sectionally dependent pada Model 1b (Hoechle, 2007).

Tabel 9 Hasil Regresi Variabel Penelitian - Diversifikasi Tidak Terkait (Model 1b)

\begin{tabular}{|l|l|l|l|}
\hline \multicolumn{1}{|c|}{$\mathbf{E}$} & \multicolumn{1}{|c|}{ Koefisien } & \multicolumn{1}{c|}{$\mathbf{P}>|\mathbf{t}|$} & \multicolumn{1}{c|}{ Korelasi } \\
\hline DU & 0,076 & $0,000^{* * *}$ & Signifikan $(+)$ \\
\hline
\end{tabular}




\begin{tabular}{|l|l|l|l|}
\hline SIZE & $-0,122$ & $0,000^{* * *}$ & Signifikan ( - ) \\
\hline LEV & $-0,082$ & 0,115 & Tidak Signifikan \\
\hline AGE & $-0,142$ & $0,019^{* *}$ & Signifikan ( - ) \\
\hline LIQ & $-0,013$ & 0,264 & Tidak Signifikan \\
\hline EX & 0,033 & $0,054^{*}$ & Signifikan ( + ) \\
\hline Konstanta & 2,566 & 0,000 & \\
\hline R-sq & 0,243 & & \\
\cline { 1 - 2 } Perusahaan & 32 & & \\
\cline { 1 - 2 } Observasi & 128 & & \\
\cline { 1 - 3 } & & &
\end{tabular}

Tanda $* * *$ berarti signifikan pada $1 \%$; tanda $* *$ berarti signifikan pada $5 \%$; tanda * berarti signifikan pada $10 \%$.

E adalah Efisiensi yang diukur dengan model BCC - Data Envelopment Analysis menggunakan Microsoft Excel. DU adalah Unrelated Diversification (Diversifikasi Produk Tidak Terkait) yang diukur menggunakan entropy index. SIZE adalah Ukuran Perusahaan yang dihitung dengan natural logaritma dari total aset perusahaan. LEV adalah leverage atau Struktur Modal yang dihitung dengan total utang bank terhadap total aset perusahaan. AGE adalah logaritma natural dari Umur Perusahaan yang dihitung atas tahun yang diteliti dikurangi dengan tahun perusahaan berdiri. LIQ adalah Likuiditas yang dihitung dengan rasio lancar (total aset lancar terhadap total liabilitas jangka pendek). EX adalah nilai tengah atas Nilai Tukar dari USD (Dolar Amerika) ke Rupiah pada tahun tersebut (dalam puluhan ribu).

Tabel 9 menunjukkan bahwa variabel independen Diversifikasi Tidak Terkait memiliki hasil koefisien positif dan korelasi signifikan. Hasil regresi Tabel 9 berlawanan dengan hipotesis $1 \mathrm{~b}$, sehingga hipotesis $1 \mathrm{~b}$ ditolak. Menurut Amihud dan Lev (1981), alasan pengaruh positif dari Diversifikasi Tidak Terkait terhadap Efisiensi karena di saat perusahaan melakukan Diversifikasi Tidak Terkait, risiko suatu perusahaan akan menurun akibat perusahaan yang berada di beberapa sub sektor industri yang berbeda-beda, sehingga perusahaan tidak bergantung hanya pada satu sub sektor industri saja. Perusahaan juga memiliki lebih banyak opsi untuk mengalokasikan sumber daya yang dimilikinya sehingga ketika satu sub sektor industri sedang mengalami penurunan, perusahaan dapat menginvestasikan sumber daya yang dimilikinya ke sub sektor industri yang memiliki prospek lebih 
baik. Menurut Khanna dan Palepu (1997), perusahaan yang melakukan Diversifikasi Tidak Terkait juga dinilai lebih kredibel oleh investor. Pandangan investor tersebut mampu membuat nilai perusahaan bertambah sehingga nilai efisiensi perusahaan dapat meningkat, mengingat salah satu proksi pengukuran efisiensi adalah nilai perusahaan (market to book value dan Tobin's Q). Khanna dan Palepu (1997) juga menyatakan bahwa perusahaan di negara-negara berkembang seperti Indonesia memang lebih cocok menerapkan strategi Diversifikasi Tidak Terkait. Akibat sistem informasi yang lemah di Indonesia, perusahaan konglomerasi (perusahaan yang Diversifikasi Tidak Terkait) lebih dimudahkan pada beberapa aspek dibandingkan dengan perusahaan fokus atau perusahaan Diversifikasi Terkait. Biasanya perusahaan Diversifikasi Tidak Terkait telah memiliki brand image yang besar dan diketahui oleh banyak orang sehingga lebih mudah memasuki lini bisnis baru, meskipun lini bisnis tersebut tidak berkaitan dengan lini bisnis saat ini. Perusahaan konglomerasi tersebut hanya perlu mempertahankan brand mereka agar tetap dipercaya oleh pemangku kepentingan untuk berhasil dalam bisnisnya. Selain itu, biaya pembangunan nama brand perusahaan Diversifikasi Tidak Terkait dapat disebarkan ke beberapa lini bisnis sehingga membuat perusahaan lebih efisien.

\section{Analisis Pengaruh Strategi Diversifikasi Internasional Terhadap Efisiensi (Model 2)}

Model 2 menggunakan metode regresi fixed effect robust, sama seperti Model 1a. Penentuan metode fixed effect berdasarkan hasil uji ketepatan model. Pemilihan opsi robust untuk memperbaiki masalah heteroskedastisitas pada Model 1a (Hoechle, 2007).

Tabel 10 Hasil Regresi Variabel Pe ne litian - Dive rsifikasi Internasional (Model 2)

\begin{tabular}{|l|l|l|l|}
\hline \multicolumn{1}{|c|}{ E } & \multicolumn{1}{|c|}{ Koefisien } & \multicolumn{1}{c|}{$\mathbf{P}>|\mathbf{t}|$} & \multicolumn{1}{|c|}{ Korelasi } \\
\hline ID & $-0,053$ & 0,177 & Tidak Signifikan \\
\hline SIZE & $-0,098$ & $0,001^{* * *}$ & Signifikan ( - ) \\
\hline LEV & $-0,028$ & 0,312 & Tidak Signifikan \\
\hline
\end{tabular}

Pengaruh Strategi Diversifikasi terhadap Efisiensi pada Perusahaan Manufaktur yang Tercatat di Bursa Efek Indonesia | 1-28 


\begin{tabular}{|l|l|l|l|}
\hline AGE & 0,125 & 0,163 & Tidak Signifikan \\
\hline LIQ & 0,022 & $0,009 * * *$ & Signifikan ( + ) \\
\hline EX & 0,071 & 0,114 & Tidak Signifikan \\
\hline Konstanta & 2,136 & 0,002 & \\
\hline R-sq & 0,095 & & \\
\hline Perusahaan & 73 & & \\
\cline { 1 - 2 } Observasi & 292 & & \\
\cline { 1 - 3 } & & &
\end{tabular}

Tanda $* * *$ berarti signifikan pada $1 \%$; tanda $* *$ berarti signifikan pada $5 \%$; tanda $*$ berarti signifikan pada $10 \%$.

E adalah Efisiensi yang diukur dengan model BCC - Data Envelopment Analysis menggunakan Microsoft Excel. ID adalah Diversifikasi Internasional yang dihitung dari penjualan ke luar negeri (ekspor) terhadap total penjualan perusahaan. SIZE adalah Ukuran Perusahaan yang dihitung dengan natural logaritma dari total aset perusahaan. LEV adalah leverage atau Struktur Modal yang dihitung dengan total utang bank terhadap total aset perusahaan. AGE adalah logaritma natural dari Umur Perusahaan yang dihitung atas tahun yang diteliti dikurangi dengan tahun perusahaan berdiri. LIQ adalah Likuiditas yang dihitung dengan rasio lancar (total aset lancar terhadap total liabilitas jangka pendek). EX adalah nilai tengah atas Nilai Tukar dari USD (Dolar A merika) ke Rupiah pada tahun tersebut (dalam puluhan ribu).

Tabel 10 menunjukkan variabel independen Diversifikasi Internasional memiliki pengaruh negatif tidak signifikan terhadap Efisiensi. Pengaruh tidak signifikan ini menyatakan bahwa dampak atas Diversifikasi Internasional belum terlalu dirasakan oleh perusahaan-perusahaan Indonesia. Menurut Carney dan Dieleman (2011), perusahaan Indonesia tidak merasakan manfaat dari Diversifikasi Internasional karena kesalahan pemilihan waktu pelaksanaan diversifikasi dan masih dalam tahap pembelajaran. Pada tahun 1967-1998 pemerintahan Presiden Soeharto, ekonomi Indonesia berkembang pesat dan kesempatan besar berfokus pada ekonomi dalam negeri. Hal tersebut membuat perusahaan-perusahaan Indonesia pada saat itu lebih tertarik bekerja sama dengan politikus untuk menjamin kekuatan perusahaan dalam memonopoli pasar dalam negeri. Akibat fokus dalam memonopoli pasar dalam negeri, perusahaan-perusahaan hanya melakukan pengembangan ke luar negeri sedikit. Ketika era globalisasi datang, perusahaan-perusahaan Indonesia belum siap 
menghadapi hal tersebut dan mengambil tindakan yang tidak membuat perusahaan menjadi efisien dan efektif (Carney dan Dieleman, 2011).

Efisiensi perusahaan Diversifikasi Internasional menurun seiring dengan peningkatan tingkat diversifikasi karena adanya peningkatan kompleksitas struktur organisasi, kesulitan koordinasi dan kontrol akan memperkuat asimetri informasi dan mendorong alokasi investasi yang tidak tepat (Gao dan Chou, 2015; Hitt et al., 1997; Kostova dan Zaheer, 1999). Adanya perbedaan kultur, regulasi pemerintah, fluktuasi kurs, perkembangan ekonomi dan kendala bahasa akan mempengaruhi kond isi perusahaan pula (Chang dan Wang, 2007; Grant, 1987). Ditambah lagi dengan adanya biaya transportasi untuk ekspor dan mahalnya tarif bea masuk yang harus dibayarkan sehingga dapat mengurangi pendapatan perusahaan (Contractor, 2007). Namun, akibat di Indonesia rata-rata setiap perusahaan hanya melakukan Diversifikasi Internasional sebanyak 20\%, maka dampak negatif ini tidak terlalu dirasakan secara signifikan.

\section{Kesimpulan, Implikasi, dan Keterbatasan}

Penelitian ini dilakukan untuk mengetahui pengaruh strategi Diversifikasi Terkait, Diversifikasi Tidak Terkait, dan Diversifikasi Internasional terhadap Efisiensi perusahaan di Indonesia. Hasil pengujian terhadap 48 perusahaan manufaktur membuktikan bahwa Diversifikasi Terkait memberi pengaruh signifikan negatif terhadap Efisiensi perusahaan manufaktur di Indonesia karena risiko yang terkumpul pada satu sub sektor industri saja dan sering salah mengambil keputusan akibat ketidakpastian perilaku perusahaan. Hasil pengujian terhadap 32 perusahaan manufaktur membuktikan bahwa Diversifikasi Tidak Terkait memberi pengaruh signifikan positif terhadap Efisiensi perusahaan manufaktur di Indonesia karena risiko yang lebih tersebar, tidak hanya dalam satu sub sektor industri saja. Selain itu, perusahaan juga memiliki lebih banyak opsi dalam menyalurkan sumber dayanya dan brand yang lebih baik. Sedangkan Diversifikasi Internasional tidak 
terlalu mempengaruhi Efisiensi perusahaan manufaktur di Indonesia karena adanya keterlambatan penerapan strategi Diversif ikasi Internasional bagi perusahaan di Indonesia.

Dari hasil penelitian ini dapat disimpulkan bagi perusahaan manufaktur di Indonesia lebih baik menerapkan strategi Diversifikasi Tidak Terkait karena investor lebih menganggap perusahaan Diversif ikasi Tidak Terkait lebih kredibel sehingga lebih mudah mendapatkan investasi. Risiko yang tersebar di berbagai sub sektor industri akan menyelamatkan perusahaan disaat satu sub sektor industri tiba-tiba mengalami masalah, terutama di negara berkembang karena sistem informasi yang lemah sehingga dapat adanya keterlambatan perolehan informasi. Pemilihan sub sektor industri dan pengalokasian sumber daya atau aset perusahaan juga penting untuk diperhatikan, agar segala keputusan membuat perusahaan lebih efisien.

Penelitian ini tidak terlepas dari keterbatasan dan kekurangan yang ada. Pertama, klas ifikasi segmen perusahaan berdasarkan kode Standard Industrial Classification (SIC code) yang diambil dari Capital IQ tidak seluruhnya sesuai dengan segmen masing-masing perusahaan saat ini dan cenderung tidak lengkap. Oleh karena itu, dilakukanlah pencarian kode SIC secara manual berdasarkan segmen yang tertera pada Capital IQ. Kesalahan pengklasifikasian sangat mungkin terjadi akibat nama segmen yang tertera pada Capital IQ tidak sama persis dengan nama segmen di kode SIC. Kedua, penelitian ini tidak membedakan apakah diversifikasi yang diterapkan oleh perusahaan merupakan sebuah hasil merger atau akuisisi atau dirintis dari awal. Ketiga, pene litian ini tidak menghitung lama setiap segmen perusahaan telah berdiri, sehingga tidak diketahui apakah waktu berperan penting dalam pengaruh Diversifikasi Terkait, Diversifikasi Tidak Terkait dan Diversifikasi Internasional terhadap Efisiensi perusahaan. Keempat, penelitian ini hanya menggunakan fungsi linear pada perhitungan strategi diversifikasi dan belum menerapkan fungsi kuadratik. Kelima, penggunaan teori masih sangat terbatas yaitu hanya teori agensi dan teori resource based. Keenam,. penelitian ini tidak meneliti pengaruh strategi Diversifikasi Terkait dan Diversifikasi Tidak Terkait terhadap Efisiensi berdasarkan sub sektor industri 
Ada beberapa saran yang dapat diterapkan untuk penelitian selanjutnya. Pertama, melakukan konfirmasi ke perusahaan yang akan diteliti terkait pengklasifikasian segmen untuk meminimalisir kesalahan pengklasifikasian kode SIC. Kedua, menambah variabel dummy untuk memisahkan perusahaan yang melakukan diversifikasi dari awal dengan perusahaan yang divers if ikasi berdasarkan merger atau akuisisi. Ketiga, menambah variabel kontrol yaitu lama waktu menerapkan diversifikasi dapat digunakan untuk mengetahui apakah lamanya waktu penerapan diversifikasi berpengaruh terhadap Efisiensi suatu perusahaan. Keempat, menggunakan fungsi kuadratik dalam perhitungan diversifikasi sehingga dapat menangkap kemungkinan pergerakan tidak linear. Kelima, menambah penerapan teori-teori yang berkaitan dengan topik penelitian ini seperti internal capital market dan market power. Keenam, mengklasifikasikan data berdasarkan sub sektor industri manufaktur untuk mengetahui apakah pengaruh Diversifikasi Terkait dan Diversifikasi Tidak Terkait dipengaruhi oleh faktor eksternal yang sesuai dengan sub sektor industri masing-masing.

Implikasi dari penelitian ini membuktikan bahwa di Indonesia, strategi diversifikasi yang terbaik untuk meningkatkan Efisiensi perusahaan manufaktur adalah Divers ifikasi Tidak Terkait. Strategi Diversifikasi Internasional tidak terlalu memberikan dampak signifikan bagi Efisiensi perusahaan, sedangkan Diversifikasi Terkait memiliki kore lasi negatif signifikan yang berarti semakin tinggi tingkat Diversifikasi Terkait semakin tidak efisien. Penelitian ini juga membuktikan bahwa semakin besar Ukuran Perusahaan dapat menurunkan Efisiensi. Oleh karena itu, pemegang saham harus memantau aset perusahaan agar dipergunakan dengan sebaik-baiknya untuk tujuan perusahaan seiring dengan pertumbuhan ukuran perusahaan.

\section{Daftar Pustaka}

Afza, T., Salhudin, C. \& Nazir, M. S. (2007). Diversification and Corporate Performance: An Evaluation of Pakistani Firms. South Asian Journal of Management, 15(3), 7-18.

Amihud, Y. \& Lev, B. (1981). Risk Reduction As A Managerial Motive For Conglomerate Mergers. Bell Journal of Economics, 12(2), 605-617.

Ansoff, H. I. (1957). Strategies for Diversification. Harvard Business Review, 113-124.

Badan Pusat Statistik. (2018). Tabel Dinamis Subjek Inflasi. Diperoleh dari https ://www.bps.go.id/subject/3/inflasi.html\#subjekViewTab 6 
Carney, M. \& Dieleman, M. (2011). Indonesia's missing multinationals business groups and outward direct investment. Bulletin of Indonesian Economic Studies, 47(1), 105-126.

Chakrabarti, A., Singh, K., \& Mahmood, I. (2007). Diversification Strategies and Performance: Evidence From East Asian Firms. Strategic Management Journal, 28, 101-120.

Chang, S. C. \& Wang, C. F. (2007). The Effect of Product Diversification Strategies on The Relationship Between International Diversification and Firm Performance. Journal of World Business, 42(1), 61-79.

Contractor, F. J. (2007). Is international business good for companies? The evolutionary or mu lti-stage theory of internationalization vs. the transaction cost perspective. Management International Review, 47(3), 453475.

Doaei, M., Anuar, M. A., \& Ismail, Z. (2015). Corporate diversification and efficiency of manufacturing firms listed in bursa malaysia. Iranian Journal of Management Studies, 8(4), 523-544.

Gao, W. \& Chou, J. (2015). Innovation efficiency, global diversification, and firm value. Journal of Corporate Finance, 30, 278-298.

Glin mourinse, D. (2014, 16 September). Ini Penyebab Ekonomi Indonesia Tidak Stabil. Sindonews.com. Diperoleh dari https://ekbis.sindonews.com/read/902066/33/ini-penyebab-ekonomi-indonesia-tidakstabil-1410859476.

Goold, M. \& Campbell, A. (1998). Desperately seeking synergy. Harvard Business Review, 76(5): 131-143

Grant, R. M. (1987). Multinationality and performance among British manufacturing companies. Journal of International Business Studies, 18(3), 79-89.

Gu jarati, D. N. \& Porter, D. C. (2009). Basic Econometrics ( $5^{\text {th }}$ Edition). McGraw - Hill: New York.

Gyan, A. K., Brahmana, R. \& Bakri, A.K. (2017). Diversification Strategy, Efficiency, and Firm Performance: Insight from Emerging Market. Research in International Business and Finance.

Hall, E. H. \& Lee, J. (1999). Broadening The View of Corporate Diversification: An International Perspective. The International Journal of Organizational Analysis, 7(1), 25-53.

Harto, P. (2005). Kebijakan Diversifikasi Perusahaan dan Pengaruhnya Terhadap Kinerja: Studi Empiris pada Perusahaan Publik di Indonesia. Simposium Nasional Akuntansi 8 Solo 15-16 September 2005. Universitas Diponegoro.

Hennart, J. (2007). The theoretical rationale for a multinationality-performance relationship. Management International Review, 47, 423-452.

Hill, C. W. L \& Jones, G. R. (1998). Strategic Management Theory: An Intergrated Approach (4th Edition). Boston: Houghton Mifflin.

Hitt, M. A., Hoskisson R. E. \& Kim H. (1997). International diversification: effects on innovation and firm performance in product - diversified firms. The Academy of Management Journal, 40(4), 767-798.

Hoechle, D. (2007). Robust standard errors for panel regressions with cross-sectional dependence. Stata Journal.

Jacquemin, A. \& Berry, C. (1979). Entropy measure of diversification and corporate growth. The Journal of Industrial Economics, 27, 359-369.

Jensen, M. C. (1986). Agency costs of free cash flow, corporate finance, and takeovers. The American Economic Review, 323-329.

Jensen, M. C. \& Meckling, W. H. (1976). Theory of the Firm: Managerial Behavior, Agency Costs, and Ownership Structure. Journal of Finance and Economics, 3, 305-360.

Khanna, T. \& Palepu, K. G. (1997). Why Focused Strategies May Be Wrong for Emerging Markets. Harvard Business Review, 75 (4), 41-51.

Kogut, B. (1985). Designing Global Strategies: Profiting from Operational Flexibility. Sloan Management Review, 27(1), $27-38$.

Kostova, T. \& Zaheer, S. (1999). Organizational Legitimacy under Conditions of Complexity: the Case of the Multinational Enterprise. Academy of Management Review, 24, 82-98.

Kotler, P. \& Armstrong, G. (2008). Prinsip-prinsip Pemasaran (Jilid 1), Jakarta: Erlangga.

Li, M. F. \& Wong, Y. Y. (2003). Diversification and economic performance - An empirical assessment of Chinese firms. Asia Pacific Journal of Management, 20(2), 243.

Lins, K. \& Servaes, H. (2002). Is Corporate Diversification Beneficial in Emerging Markets? Financial Management, 31, 5-31.

Montgomery, C. \& Wernerfelt, B. (1988). Diversification, Ricardian Rents, and Tobin's q. RAND Joumal of Economics, 19(4). 
Muzyrya, Y. (2010). The relationship between product and international diversification: The effect of asset dispersion and asset diversity on firm performance.

Palepu K. (1985). Diversification Strategy: Profit Pe rformance and the Entropy Measure.

Penrose, E. T. (1959). The Theory of The Gro wth of The Firm, Oxford: Basil Blackwell.

Peteraf, M. A. (1993). The Cornerstone of Competitive Advantage: A Resource-Based View. Strategic Management Journal, 14, 179-191.

Qian, G. (1997). Assessing Product-Market Diversification of U.S. Firms. Management International Review, 37(2), 127-149.

Rugman, A. M. \& Oh, C. H. (2010). Does the regional nature of multinationals affect the multinationality and performance re lationship?. International Business Review, 479-488.

Rumelt, R. P. (1974). Strategy, Structure, and Econo mic Performance. Harvard University Press.

Satoto, S. H. (2009). Strategi Diversifikasi Terhadap Kinerja Perusahaan. Jurnal Keuangan dan Perbankan, 13(2), 280-287.

Tanwar, R. (2013). Porter's Generic Competitive Strategies". IOSR Journal of Business and Management. 15, 11-17.

Tipuric, D. \& Darabos, M. (2012). The Frequency of Implementing Diversification Strategy in Croatia.

Tyarani, G. D. (2016). Kointegrasi Bursa Saham A merika, China, Korea Selatan, Jepang dan Indonesia Periode Tahun 2011-2015.

Utama, A. P., Wahyono, H. \& Witjaksono, M. (2016). Efisiensi Pengambilan Keputusan Sumber Daya Ekonomi Konsumsi Produksi Mahasiswa. Jurnal Pendidikan: Teori, Penelitian, dan Pengembangan, 1(4), $712-$ 716.

Wernerfelt, B. (1984). A Resource-Based View of the Firm. Strategic Management Journal, 5(2), 171-180.

Wiersema, M. F., \& Bowen, H. P. (2011). The Relationship between International Diversification and Firm Performance: Why It Remains A Puzzle. Global Strategy Journal, 1, 152-170. 